\title{
Therapy for Immunoglobulin D Plasma Cell Myeloma
}

\author{
Robert Peter Gale \\ Haematology Research Centre, Division of Experimental Medicine, Department of Medicine, \\ Imperial College London, London, UK
}

There is a circularity to life. My $\mathrm{PhD}$ advisor at UCLA was Prof. John Fahey who, in 1965 with David Rowe, discovered immunoglobulin $\mathrm{D}(\mathrm{IgD})$ in the serum of a young man with previously undiagnosed plasma cell myeloma [1]. Fifty years later I am asked to comment on an article in this journal by Kang et al. [2] describing therapy advances they attribute to new anti-myeloma drugs.

IgD plasma cell myeloma is rare ( $<2 \%$ of cases) [3]. It typically occurs in young males and is characterized by a small or absent M-protein spike on serum protein electrophoresis, extra-medullary involvement, osteolytic lesions, systemic amyloidosis, hypercalcaemia, a $\lambda$-lightchain bias, Bence Jones proteinuria, kidney failure, and a worse prognosis than IgG and IgA forms of plasma cell myeloma [4]. This worse prognosis reflects these adverse biological features as well as more advanced disease at diagnosis. Part of this diagnostic delay is attributed to the absent $\mathrm{M}$-spike on routine blood examinations for unrelated reasons [5].

The question posed by the authors is whether persons with IgD plasma cell myeloma receiving what they term novel drugs (is something novel if it has been used for 15 years?) and an autotransplant are better than persons receiving conventional therapy and an autotransplant. They conclude that this is likely so; they are probably correct. However, the issue for me is to comment on whether the data they present prove this conclusion, which is an entirely different matter.

\section{KARGER}

() 2018 S. Karger AG, Basel

E-Mail karger@karger.com

www.karger.com/aha
A real statistician could have a field day highlighting problems with this study: its retrospective nature, few, non-consecutive subjects, selection biases, historical controls (obviously novel drugs were given to the most recent subjects), etc. There is no statistical comparison of the cohorts for progression-free survival (PFS) or survival. The authors' explanation is that there were too few subjects. I agree. However, with wide $95 \%$ confidence intervals we cannot accurately say whether the statistical model typically tested for significance with a $p$ value, the null hypothesis, is a good explanation of the data observed or more extreme results [6]. As for performing multivariate analyses on a sample size of 22: forget about it.

One curiosity in the data reported is that although median PFSs were similar (7 and 8 months) for subjects receiving or not receiving novel drugs, survivals were seemingly vastly different (13 and 39 months). This means that if novel drugs are effective in improving survival their efficacy is after progression, not before. We must, of course, be cautious in accepting these data as PFS is typically (but not always) a somewhat reasonable surrogate of survival. Data regarding the efficacy of maintenance therapy after autotransplant in this typescript in very few subjects should be ignored; the issue has been addressed in large randomized trials $[7,8]$.

Others have studied a slightly different question: whether persons with IgD plasma cell myeloma have a different outcome than others with or without high-dose

Robert Peter Gale, MD, PhD, DSc (hc), FACP, FRSM Haematology Research Centre 


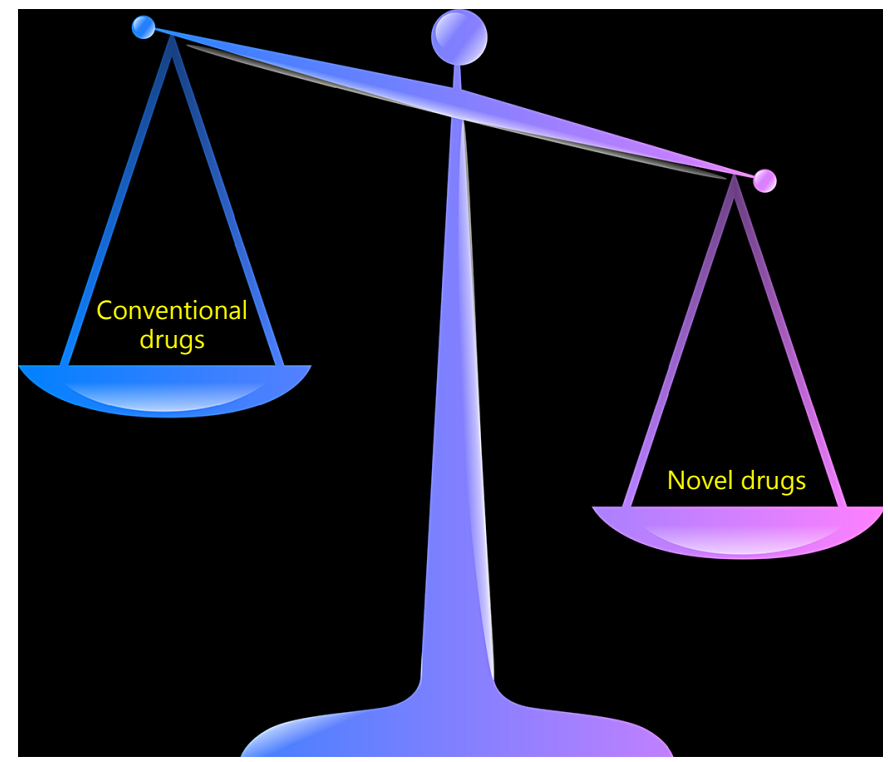

Fig. 1. Weight of evidence on the efficiency of new drugs in immunoglobulin D plasma cell myeloma.

therapy and an autotransplant. Results are contradictory [9-12]. In a study from the Centre for Blood and Marrow Research (CIBMTR) in 36 subjects my colleagues and I found similar outcomes to persons with IgG and IgA plasma cell myeloma [13]. However, another study in 17 subjects reported worse outcomes [14].

The bottom line of all this? Members of a jury are instructed to consider the balance of evidence in reaching an opinion. This concept acknowledges the fact that the truth cannot be known with absolute certainty: did the defendant kill the victim if there are no eye witnesses and the defendant denies the killing? What we are asked to do is to imagine a balance scale where evidence for and against a hypothesis is weighed. Which way does the balance tilt? In this instance, it is in favour of novel drugs, with or without high-dose therapy and an autotransplant, improving outcomes of persons with IgD plasma cell myeloma. Can I prove it? No. Can the authors prove it? No. However, this typescript tilts the balance a bit further towards a benefit (Fig. 1).

\section{Acknowledgements}

R.P.G. acknowledges support from the National Institute of Health Research (NIHR) Biomedical Research Centre funding scheme.

\section{Disclosure Statement}

R.P.G. is a part-time employee of Celgene Corp.

\section{References}

1 Rowe DS, Fahey JL: A new class of human immunoglobulins. I. A unique myeloma protein. J Exp Med 1965;121:171-184.

$\checkmark 2$ Kang J, Hong JY, Yoon DH, Kim S, Lee KM, Park JS, et al: Efficacy and survival outcome associated with the use of novel agents and autologous stem cell transplantation in cases of immunoglobulin D multiple myeloma in Korea. Acta Haematol 2018, DOI: 10.1159/ 486664.

3 Kyle RA, Gertz MA, Witzig TE, Lust JA, Lacy MQ, Dispenzieri A, et al: Review of 1,027 patients with newly diagnosed multiple myeloma. Mayo Clin Proc 2003;78:21-33.

-4 Blade J, Lust JA, Kyle RA: Immunoglobulin D multiple myeloma: presenting features, response to therapy and survival in a series of 53 cases. J Clin Oncol 1994;12:2398-2404.

5 Shimamoto Y, Anami Y, Yamaguchi M: A new risk grouping for IgD myeloma based on analysis of 165 Japanese patients. Eur J Haematol 1991;47:262-267.
Gale RP, Hochhaus A: What is the (p-) value of the P-value? Leukemia 2016;10:1965-1967.

-7 McCarthy PL, Holstein SA, Petrucci MT, Richardson PG, Hulin C, Tosi P, et al: Lenalidomide maintenance after autologous stem-cell transplantation in newly diagnosed multiple myeloma: a meta-analysis. J Clin Oncol 2017;35:3279-3289.

-8 Barosi G, Gale RPG: Is there expert consensus on expert consensus? Bone Marrow Transplant 2018, in press.

9 Wechalekar A, Amato D, Chen C, Stewart K, Reece D: IgD multiple myeloma - a clinical profile and outcome with chemotherapy and autologous stem cell transplantation. Ann Hematol 2005;84:115-117.

10 Maisnar V, Hájek R, Scudla V, Gregora E, Büchler T, Tichý M, et al: High-dose chemotherapy followed by autologous stem cell transplantation changes prognosis of $\operatorname{IgD}$ multiple myeloma. Bone Marrow Transplant 2007;41:51-54.
Pisani F, Petrucci MT, Giannarelli D, Bongarzoni V, Montanaro M, De Stefano V; Multiple Myeloma GIMEMA-Latium Region Working Group, Italy: IgD multiple myeloma a descriptive report of 17 cases: survival and response to therapy. J Exp Clin Cancer Res 2012;31:17.

12 Wang GR, Sun WJ, Chen WM, Huang ZX, Zhang JJ, An N, et al: Immunoglobulin D multiple myeloma: disease profile, therapeutic response and survival. Acta Hematol 2016; 136:140-146.

13 Reece DE, Vesole DH, Shrestha S, Zhang MJ, Perez WS, Dispenzieri A, et al: Outcome of patients with IgD and IgM multiple myeloma undergoing autologous hematopoietic stem cell transplantation: a retrospective CIBMTR study. Clin Lymph Myeloma Leuk 2010;10: 458-463.

14 Morris C, Drake M, Apperley J, Iacobelli S, van Biezen A, Bjorkstrand B, et al: Efficacy and outcome of autologous transplantation in rare myelomas. Haematologica 2010;95:2126-2133. 